\title{
Kaitan Konflik dan Nilai-Nilai Sosial dalam Novel Pasar Karya Kuntowijoyo
}

\author{
Widiasih $^{1)}$ \\ Universitas Indraprasta PGRI \\ Jalan Nangka No. 58 C/TB. Simatupang, Tanjung Barat, Jakarta Selatan 12530
}

\author{
Apsanti Djokosujanto ${ }^{2}$ \\ Universitas Indraprasta PGRI \\ Jalan Nangka No. 58 C/TB. Simatupang, Tanjung Barat, Jakarta Selatan 12530 \\ widiasih_oel@yahoo.com ${ }^{1)}$
}

\begin{abstract}
The purpose of this study is to find out: 1) Conflict conveyed in the storyline in the novel Pasar Pasar by Kuntowijoyo 2) Relationship of social values and social groups in the novel Pasar Pasar by Kuntowijoyo. Data collection techniques used are library and refer and note techniques. Listen and note technique means that the researcher as a key instrument carries out careful, directed, and careful observations of the main data source as the target of the researcher in the form of the novel text of the Market in obtaining the desired data. This research is a qualitative research that is descriptive in nature and uses a semiotic method. This research yields several findings: 1) Reveals a description of the conflict between market users and market managers that cause conflict. The conflict was caused by the pigeons of Pak Mantri and the personal interests of the figures. 2) Prove that conflict brings social change and is related to social values. social values have to do with social groups, which can bring social change to social groups. there is no responsibility of the managers towards the community that is related to the market user community groups who are aware of the interests of their groups and their rights.
\end{abstract}

Keywords: conflict, social values, novels

\begin{abstract}
Abstrak
Tujuan penelitian ini adalah untuk mengetahui: 1) Konflik yang disampaikan dalam alur cerita pada novel Pasar karya Kuntowijoyo 2) Hubungan nilai-nilai sosial dan kelompok sosial dalam novel Pasar karya Kuntowijoyo. Teknik pengumpulan data yang digunakan adalah teknik pustaka dan simak serta catat. Teknik simak dan teknik catat berarti peneliti sebagai instrument kunci melakukan penyimakan secara cermat, terarah, dan teliti terhadap sumber data utama sebagai sasaran peneliti yaitu berupa teks novel Pasar dalam memperoleh data yang diinginkan. Penelitian ini adalah penelitian kualitatif yang bersifat deskriptif dan menggunakan metode semiotik. Penelitian ini menghasilkan beberapa temuan: 1) Mengungkapkan deskripsi pertentangan pengguna pasar dan pengelola pasar yang menimbulkan konflik. Konflik disebabkan oleh burung-burung dara Pak Mantri dan kepentingan-kepentingan pribadi para tokoh. 2) Membuktikan bahwa konflik membawa perubahan sosial dan berkaitan dengan nilai-nilai sosial masyarakat. nilai-nilai sosial ada hubungannya dengan kelompok sosial masyarakat, yaitu dapat membawa perubahan sosial bagi kelompok sosial masyarakat. tak adanya tanggung jawab para pengelola terhadap masyarakat yang dipertengtangkan dengan kelompok masyarakat pengguna pasar yang menyadari kepentingan kelompoknya dan haknya.
\end{abstract}

Kata Kunci: konflik, nilai-nilai sosial, novel

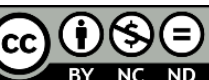

Creative Commons Attribution-NonCommercial-NoDerivatives 4.0 International License 


\section{PENDAHULUAN}

Novel adalah cerita rekaan yang bersifat naratif atau wacana naratif. Pengarang dalam novelnya menawarkan berbagai permasalahan kehidupan manusia. Seluruh kehidupan yang dialami manusia, baik dalam kehidupan pribadinya, kemanusiaannya sebagai manusia sosial, bahkan dalam kehidupan setelah menghayati berbagai permasalahan dengan serius. Penghayatan ini yang diungkapkan kembali dalam dunia fiksi yang imajinatif. Bersifat imajinatif, tetapi masuk akal dan mengandung kebenaran yang mendramatisasikan hubungan antar manusia.

Semi (1998: 32) berpendapat bahwa novel adalah karya yang mengungkapkan sisi kemanusiaan yang mendalam dan diungkapkan secara halus. Bentuk karya sastra yang memiliki sebuah karakteristik tersendiri itulah novel. Novel tergambar jelas dengan adanya tokoh-tokoh yang memiliki karkater, dirangkai dengan alur yang runtut dan sesuai, berakhir pada sebuah klimaks.

Novel bercerita tentang berabgai problematika manusia dengan sesama dan interaksinya dengan lingkungan, diri sendiri dan Tuhan. Novel merupakan reaksi pengarang terhadap lingkungannya setelah digelutinya secara intens. Novel adalah karya imajinatif yang berunsur estetik, dilandasi juga kesadaran dan tanggung jawab dengan menawarkan model kehidupan sesuai dengan idealnya pengarang.

Wellek \& Warren (1989:113-114) berpendapat bahwa sebuah fiksi isinya harus menarik, strukturnya harus koheren dan mempunyai tujuan estetika. Pembaca secara tidak langsung harus dapat merasakan, mengayati, dan belajar berbagai masalah kehidupan yang disajikan pengarang. Maka itulah sebabnya, novel dapat memberikan edukasi terhadap pembacanya yaitu membuat pembaca menjadi arif dan bijaksana. Dapat merasakan kepekaan terhadap sesamanya, berlaku simpati bahkan empati kepada orang lain. Menurut Al-Ma'ruf (2006), selayaknya sebuah novel dapat memperkaya khazanah batin pembacanya.

Damono (1979:3) berpendapat novel merupakan salah satu karya sastra prosa yang mengungkapkan seluruh episode perjalanan hidup tokoh ceritanya. Kehidupan seseorang dengan orang-orang di sekelilingnya dengan menonjolkan watak dan sikap pelaku yang memberikan gambaran tentang masalah kemasyarakatan, terkadang tidak bisa dipisahkan dengan gejolak atau keadaan masyarakat yang melibatkan penulis dan kadang-kadang juga pembacanya.

Novel merupakan hasil pengalaman pengarang dalam menghadapi lingkungan sosialnya dengan imajinasi pengarang. Novel merupakan ungkapan kesadaran pengarang yang berhubungan dengan kepekaan, pikiran, perasaan, dan hasratnya dengan realitas yang dihadapi pengarang dipadu dengan pengalaman hidupnya. Novel merupakan perwujudan pikiran, perasaan, ilmu, ide, semangat, dan keyakinan dari pengarang yang dituangkan dalam bentuk tulisan atau cerita (Rahman dkk., 2018: 13). Oleh karena itu, novel sering mengungkapkan berbagai realitas hidup yang terkadang tidak terduga oleh pembaca.

Kuntowijoyo dalam novel Pasar mengangkat masalah perubahan sosial masyarakat. Perubahan sosial yang mengakibatkan terjadinya konflik di antara tokoh-tokohnya. Kuntowijoyo menyajikan konflik para tokoh di tengah-tengah kehidupan pasar di sebuah Kecamatan Gemolong. Konflik mulai muncul ketika 
pedagang yang berjualan di pasar Gemolong tidak mau membayar karcis pasar. Para pedagang kesal karena merasa dirugikan oleh ulah banyak burung dara hewan peliharaan Pak Mantri (kepala pasar) yang berkeliaran di pasar itu.

Novel ini diangkat di era tahun 1971 yang mengangkat kehidupan masyarakat Jawa yang menjunjung tinggi nilai-nilai budaya Jawa. Nilai-nilai Jawa tersebut penting ditanamkan dalam kehidupan sekarang di zaman globalisasi. Semakin banyak nilai-nilai kehidupan yang hilang ditelan zaman. Masyarakat di era digital pada saat ini semakin kurang kepeduliannya antara manusia yang satu dengan manusia yang lain. Lebih mementingkan kepentingannya sendiri daripada kepentingan masyarakat luas.

Rumusan masalah dalam penelitian ini adalah bagaimana konflik dan nilainilai sosial dalam novel Pasar karya Kuntowijoyo. Tujuan penelitian ini adalah untuk mengetahui: 1) Konflik yang disampaikan dalam alur cerita pada novel Pasar karya Kuntowijoyo 2) Hubungan nilai-nilai sosial dan kelompok sosial dalam novel Pasar karya Kuntowijoyo.

\section{METODE}

Penelitian ini menggunakan metode semiotik. Jenis penelitiannya menggunakan jenis penelitian kualitatif. Penelitian kualitatif ini bertujuan untuk memperoleh pemahaman, mengembangkan teori, dan menggambarkan realitas yang kompleks. Penelitian kualitatif penekanannya bukan pada kesimpulan, tetapi cenderung menekankan sebuah proses yang menghasilkan makna. Data deskriptif yang diperoleh yaitu novel Pasar karya Kuntowijoyo sebagai sumber primer. Sedangkan data sekundernya diperoleh dari studi kepustakaan, membaca buku, artikel, jurnal, dan internet.

Pada penelitian ini mengungkap tiga tataran yang menyangkut aspek (tataran) sintaktika, yaitu pengaluran, alur, aspek semantika. Pengaluran berisi tentang urutan satuan isi cerita/sekuen, episode dalam cerita, pusat-pusat peristiwa. Alur adalah hubungan logis dari keseluruhan isi cerita sehingga menjadi satu kesatuan. Aspek semantika yaitu hubungan di luar kebahasaan. Tentang tokoh, karakter, tokoh sebagai individu dan bagian dari masyarakat.

\section{HASIL DAN PEMBAHASAN}

\section{Hasil}

Hasil dari penelitian ini dasajikan dalam bentuk tabel sebagai berikut:

Tabel 1. Temuan di Setiap Episode

\begin{tabular}{cl}
\hline Episode Cerita & \multicolumn{1}{c}{ Temuan } \\
\hline 1. Pak Mantri Pasar Sebagai Kepala Pasar & $\begin{array}{l}\text { Dan masya-Allah! Kalau engkau menghitung, } \\
\text { burung-burung dara yang berkeliaran masih } \\
\text { jauh lebih banyak daripada orang-orang itu! }\end{array}$
\end{tabular}


2. Gambaran Pasar

3. Pelepasan Burung Merpati Pak Mantri

4. Kemarahan Pedagang Pasar

5. Penolakan Pemerintah

6. Pasar dan Bank Kredit Illegal Milik Kasan Ngali

7. Kesadaran Pak Mantri yang Menyelamatkan Pasar

8. Kasan Ngali Bangkrut
Burung-burung itu melintas di mana-mana. Hinggap di mana-mana. Berjalan di manamana. Menahi di mana-mana

"Pasar itudilingkari dengan pagar kawat berduri, tonggak-tonggak beton, dan pohanan krangkungan setinggi orang. Tetapi jangan ditanya keadaannya! Kawat-kawat berduri itu telah karatan, putus di sana sini, mengendor memberi jalan, dapt dikatakan pagar itu tidak lagi berguna."

"Burung-burung dara berlompatan di tanah, di pagar, sekitar kantor, di atap, di pohon asama."

"Tiga ekor burung dara telah mencocok berasku. Berapa harus dibayar, kalau aku mau menghitung. Masih diminta karcis pasar lagi! Mestinya aku minta ganti rugi!" orang mengangguk-angguk. Rugi, rugi itu! Betul tak mau bayar!"

"Tetapi kami tak mengurusi pembunuhan burung-burung. Perkara semacam itu tugas pamong praja. Pak Camat tentu bisa, Pak. Polisi hanya mengurus pembunuhan yang benar-benar pembunuhan, begitu."

"Benarlah! Ketika Paijo keluar dari rumah Kasan Ngali, ia terkejut. Di pekarangan Kasan Ngali sudah berdiri los-los pasar! Dan pedagangnya sekali. Tentu saja Kasan Ngali sengaja menggiring mereka ke pekarangannya."

"Sambil tiduran ia memikirkan, kalau perlu burung-burung daranya bisa saja ditangkap. Supaya orang-orang pasar selamat. Tentang caranya bisa diserahkan pada Paijo. Keputusannya yang luar biasa itu memberi harapan, bahkan baginya sendiri.dan ia setuan itu mempunyai kerelaan yang demikian besar. Semoga diterima amalnya!",

"Sekarang sudah bubar! Uang siapa kalian kira! Uang buyutmu! Uang kakekmu! Tidak ada lagi kredit! Tidak ada uang! Pemerasan!"

\section{Pembahasan}

Berikut disampaikan pembahasan terkait temuan-temuan dalam setiap episode cerita:

\section{Pak Mantri Pasar Sebagai Kepala Pasar}


Novel Pasar jalinan ceritanya diawali dengan mengetengahkan tokoh Pak Mantri yang menjadi tokoh utama dalam novel ini. Melalui tokoh Pak Mantri, pengarang mencoba menggambarkan sosok manusia Jawa yang tetap memegang teguh nilai-nilai budaya Jawa di tengah gelombang perubahan yang terjadi di masyarakat. Nilai Jawa yang diyakini Pak Mantri adalah bahwa dalam menjalani hidup manusia harus bersikap samadya. Meskipun memiliki jabatan, Pak Mantri tidak menggunakannya untuk menumpuk kekayaan. Kehidupannya tetap bersahaja. Dengan sikap samadya manusia akan dapat mengukur kemampuannya, tidak memaksakan kehendak untuk meraih sesuatu yang tidak mungkin diraihnya.

Pak Mantri dalam menjalankan tugasnya benar-benar bisa dikatakan sebagai pegawai teladan. Peraturan pasar sangat ia junjung tinggi demi mencapai kemajuan bagi pasar yang ia kelola. Ia harus rela berangkat pagi-pagi untuk mengecek kesiapan pasar untuk digunakan para pedagang, dan lain sebagainya. Termasuk menggalang penarikan karcis bagi setiap pedagang yang berjualan di pasar yang ia kelola. Ia hidup sendiri di usianya yang tua, tidak menikah. Ikat pinggang hitam melilit perut, sepasang sepatu sandal dengan kaus kaki putih, di kepalanya sebuah topi linen putih, tas coklat kehitaman, itulah Pak Mantri Pasar.

Pak Mantri memiliki satu-satunya hiburan yaitu burung-burung peliharaannya, yaitu perkutut, puter, juga burung dara yang jumlahnya sangat banyak dan dibiarkan bebas beterbangan di sekitar pasar. Baginya, hak makhluk hidup untuk hidup sangat penting. Ia sangat disegani semua orang dikampungnya, begitu juga Kepala Polisi dan Pak Camat.

Pak Mantri sebagai Mantri Pasar berusaha menjalankan tugasnya dengan berlandaskan nilai-nilai Jawa yang diyakininya. Hal ini terlihat pada sikapnya dalam menghadapi setiap persoalan dan juga pada petuah-petuahnya yang sering ia berikan kepada Paijo. Memang, sebagai orang yang punya jabatan, kadang ia juga terlihat suka memerintah, juga mudah marah jika yang diperintah tidak dapat menjalankan tugasnya dengan baik. Hal ini dia lakukan semata-mata karena tugas yang diamanatkan kepadanya.

Kegiatan mengelola pasar awalnya berjalan dengan tenang. Dengan berjalannya waktu terjadi masalah. Para pedagang berjualan di luar pasar, loslos pasar terlihat sepi. Pak Mantri mulai mendapat cacian dari pedagang. Para pedagang tidak mau lagi membayar karcis. Mereka mogok membayar karcis, mereka merasa dirugikan oleh tingkah burung-burung dara milik Pak Mantri. Burung dara dipelihara dikantornya dan jumlahnya sudah tidak terhitung. Buktinya :

"Dan masya-Allah! Kalau engkau menghitung, burung-burung dara yang berkeliaran masih jauh lebih banyak daripada orang-orang itu! Burung-burung itu melintas di mana-mana. Hinggap di mana-mana. Berjalan di mana-mana. Menahi di mana-mana. " (Kuntowijoyo, 2017: 2)

Pak Mantri punya aturan yang tak akan ditemui di pasar lain atau tempat lain di Kecamatan tersebut, bahkan mungkin di seantero negeri ini soal burung 
dara. Pak Mantri yang laki-laki Jawa itu menghendaki pasarnya diliari burung dan orang-orang pasar dilarang mengganggu kehidupan burung. Jumlah burung dara yang berkeliaran di pasar lebih banyak daripada orang-orang di sana. Burung-burung tersebut hinggap di mana-mana dan menahi di manamana. Sumber dari burung-burung itu ialah kantor pasar. Pak Mantri sengaja membuat puluhan pagupon (kandang burung) di bagian atap kantornya demi menampung burung-burung itu yang mungkin hampir separuhnya entah datang dari mana. Sebab aturan itu, Pak Mantri dicemooh dan diumpat orang-orang pasar yang dagangannya terganggu kehadiran burung dara yang dipeliharanya. Jika ia seorang Mantri yang bijak, tentu saja cemooh itu masuk ke sanubarinya, tetapi ia tak peduli. Orang pasar hanya tahu kalau aturan soal burung dara itu tak masuk akal.

Kesenangan atau kepentingan pribadi memelihara burung dara ternyata menjadi penyebab konflik dengan masyarakat pasar. Pengarang menggambarkan seseorang tokoh yang kental dengan nilai-nilai Jawa, tetapi memaksakan kehendaknya. Menunjukkan bahwa dia bukanlah dewa, tetapi manusia biasa. Walau dalam bicaranya Pak Mantri selalu rendah hati dan hidup sesuai dengan nilai Jawa, tetapi dalam praktiknya dia tidak menyadari bahwa dia sudah menggunakan wewenang, jabatan, kekuasaan, dan keegoisannya sebagai Kepala Pasar. Merasa bahwa memiliki kekuasaan, maka Dia melakukan apa saja yang menurutnya baik untuk dirinya sendiri.

Bertahun-tahun menjabat sebagai Kepala Pasar baru kali ini diprotes banyak orang. Sampai-sampai para pedagang mengancam akan membunuh semua burung-burung itu. Menghadapi masalah ini Pak Mantri merasa sakit hati. Pak Mantri masih menganggap bahwa bagaimanapun juga burung-burung itu memiliki hak untuk hidup. Pak Mantri tidak menyadari bahwa masalah utama pedagang pasar tidak mau membayar karcis disebabkan oleh burungburung miliknya. Dengan masalah ini sama saja Pak Mantri mencoreng dirinya sendiri. Karena hoby-nya ini dia melupakan aturan bahkan melanggar aturan yang dibuatnya sendiri.

\section{Gambaran Pasar}

Pasar yang menjadi latar dalam novel Pasar karya Kuntowijoyo adalah pasar di sebuah kecamatan Gemolong. Gemolong adalah sebuah kecamatan di Kabupaten Sragen, Provinsi Jawa Tengah. Kecamatan Gemolong terletak di sebelah barat ibu kota Kabupaten Sragen dengan jarak kurang lebih 20 km dari Kota Solo.

Pasar dalam cerita ini digambarkan pengarang sebuah pasar yang kondisinya sangat memprihatinkan. Karena usia gedung pasar tersebut yang sudah lama sehingga kondisi los-los pasar yang terbuat dari besi sudah berkarat, atap bangunan sudah lumutan. Bangunan pasar sejak berdiri belum pernah diperbaiki. Pagar sekeliling pasar sudah banyak yang rusak, pohonpohon dibiarkan tumbang berserakan di halaman. Buktinya :

"Pasar itudilingkari dengan pagar kawat berduri, tonggak-tonggak beton, dan pohanan krangkungan setinggi orang. Tetapi jangan ditanya keadaannya! Kawat-kawat berduri itu telah karatan, putus di 
sana sini, mengendor memberi jalan, dapt dikatakan pagar itu tidak lagi berguna." (Kuntowijoyo, 2017: 3)

Tidak hanya kondisi pasar yang tidak terawat namun adanya burungburung dara yang berkeliaran ke sana ke mari dengan bebasnya mengakibatkan pedagang sangat kesal. Dagangan di makan, ada yang hinggap mengacak-acak dagangan, bahkan menumpahkan dagangan. Ini mengakibatkan kerugian pada pedagang. Pasar menjadi semakin porak-poranda. Akibatnya pembeli enggan masuk ke los-los pasar untuk membeli kebutuhan maka para pedagang menggelar dagangannya di tepi jalan raya di depan pasar. Pasar semakin semrawut, pedagang tidak lagi mengindahkan peraturan yang ada. Hal ini pasti berdampak pada aturan lalu lintas. Jalan raya akan terganggu dengan adanya pedagang yang berjualan di tepi jalan. Juga berbahaya bagi keselamatan pedagang dan pembeli, tetapi demi dagangannya laku pedagang memilih dengan risiko.

Pengarang tampaknya ingin menunjukkan bahwa pasar ini tidak dikelola dengan baik. Menunjukkan bahwa Pak Mantri terlalu nyaman dengan kondisi yang selama ini aman-aman saja. Sehingga pekerjaannya tidak terlalu fokus pada kepentingan pasar namun lebih mengutamakan kesenangannya. Pak Mantri tidak memberikan servis yang baik kepada konsumen. Pedagang lebih sering bertemu dengan Paijo dibanding dengan Pak Mantri. Pedagang tidak bisa menyampaikan protesnya, aspirasinya, keluhannya. Pedagang tidak bisa menuntut haknya sebagai pedagang yang seharusnya mendapatkan hak penuh atas pelayanan yang baik dari Kepala Pasar. Semua urusan pasar diserahkannya pada Paijo.

Efek dari adanya burung-burung dara yang berkeliaran di pasar ini juga dialami oleh Bank Pasar yang terletak di sebelah Kantor Pasar. Depan Kantor Bank Pasar terdapat pagupon (rumah-rumah burung dara). Tembok Kantor Bank Pasar yang semula warnanya putih, sekarang berwarna kekuningan karena terkena tahi-tahi burung-burung dara. Ini menjadikan gedung dan halaman Kantor Bank Pasar menjadi kumuh dan kotor. Hal ini juga mempengaruhi kenyamanan para nasabah bank. Selain kenyamanan para nasabah yang sejatinya nasabah itu adalah pedagang pasar juga sepi penabung. Karena pedagang merugi maka mereka tidak bisa menyisihkan uang untuk ditabung. Dengan demikian bank menjadi sepi penabung.

Pasar kondisinya sangat memprihatinkan jika dilihat dari dari segi kenyamanan, keamanan, bahkan segi perekonomian. Seharusnya pasar menjadi tempat di mana masyarakat dapat mengadakan kegiatan jual beli, menjadi pusat perekonomian masyarakat, tetapi tidak dapat diharapkan lagi sesuai fungsinya. Pedagang berharap dapat mengais rezeki dari berjualan di pasar. Seharusnya pembeli juga dapat membeli bahan makanan dan keperluan rumah tangga dengan kualitas yang baik. Namun, sebaliknya, barang yang dibeli kotor dan tidak berkualitas. Jika kondisinya seperti ini ada kemungkinan pasar ini akan bangkrut, dan perekonomian masyarakat di sekitar akan mengalami kemunduran. 


\section{Pelepasan Burung Merpati Pak Mantri}

Pak Mantri Pasar memiliki kesukaan atau hoby memelihara burung. Dia senang memelihara burung, dalam bahasa Jawanya memiliki klangenan. Salah satunya adalah burung merpati atau burung dara. Burung dara itu dipelihara dari jumlah yang sedikit sampai beranak-pinak menjadi sangat banyak. Pak Mantri sangat menikmati dengan burung-burung itu. Dia pelihara di kantor, bukan di rumah. Pak Mantri Pasar memang bekerja dari pagi hingga petang. Jadi sebagian besar waktunya berada di pasar. Sudah bertahun-tahun dia bekerja sebagai Mantri Pasar sehingga Kantor Pasar serasa rumah kedua baginya.

Burung-burung merpati atau burung dara sengaja dilepas bebas oleh Pak Mantri. Burung-burung itu berkeliaran di pasar. Karena sudah tidak terhitung jumlahnya maka Pak Mantri tidak mampu lagi membuat kandang yang layak, burung-burung itu akhirnya membuat sangkar masing-masing di sekitar Kantor Pasar, Kantor Bank Pasar. Ada yang berkandang di bagian atas tembok, di bawah atap, di mana saja yang memungkinkan untuk bersarang.

Burung-burung ini diterbangkan bebas dan dipelihara di kantor pasar maka ini sangat mangganggu aktivitas masyarakat pasar dan sekitarnya. Burung-burung itu melintas di mana-mana. Hinggap di mana-mana. Berjalan di mana-mana. Menahi di mana-mana. Meninggalkan kotoran di mana-mana. Memakan dagangan pedagang pasar. Buktinya :

"Burung-burung dara berlompatan di tanah, di pagar, sekitar kantor, di atap, di pohon asama.” (Kuntowijoyo, 2017: 7)

Burung-burung yang banyak jumlahnya, yang sudah tidak dapat dihitung dengan jari itu telah menjadi hama. Terbang bebas, memakan jualan para pedagang beras, jagung, kacang-kacang, dsb. Menumpahkan barang dagangan pedagang jika burung itu diusir dengan paksa. Kotorannya bahkan mengenai barang-barang dagangan para penjual dan itu sangat mengganggu. Bank Pasar yang berada di sebelah kantor pasar juga terkena masalah lantaran burung-burung dara. Pagupon-pagupon terletak di depan Kantor Bank sehingga sangat mengganggu pemandangan, kebersihan sekitar Kantor Bank. Akhirnya Kantor Bank menjadi sepi pengunjung, disebabkan pedagang tidak mendapatkan keuntungan juga suasana bank yang tidak nyaman.

Pak Mantri tidak melihat kesulitan orang lain. Bahwa hoby-nya ini sangat mengganggu bahkan merugikan orang lain. Dipikirnya sah-sah saja dia memelihara burung, tidak ada yang boleh protes, jika protes dianggap melawan dan membangkang.

\section{Kemarahan Pedagang Pasar}

Burung dara membuat masalah bagi ekonomi pasar. Kondisi ekonominya menjadi terhambat. Disadari betul oleh seluruh masyarakat pasar bahwa kondisi pasar rusak, tidak nyaman, terganggu aktivitasnya. Mereka protes kepada pemilik burung yang sekaligus adalah Kepala Pasar. Mereka tidak mau terus-menerus dalam kondisi demikian. Mereka menuntut haknya sebagai pedagang yang sudah membayar pajak. Namun, protes itu hanya bisa disampaikan kepada Paijo sebagai petugas penarik karcis. Pedagang tidak bisa 
menyalurkan Protes langsung kepada Kepala Pasar karena Kepala Pasar tidak pernah berkeliling di pasar. Pedagang jarang bertatap muka dengan Pak Mantri. Protes diwujudkan dengan penolakan pembayaran karcis pasar. Para pedagang marah, dan Paijolah yang terkena imbasnya, dia dimaki-maki oleh pedagang. Bukti kutipannya:

"Tiga ekor burung dara telah mencocok berasku. Berapa harus dibayar, kalau aku mau menghitung. Masih diminta karcis pasar lagi! Mestinya aku minta ganti rugi!" orang mengangguk-angguk. Rugi, rugi itu! Betul tak mau bayar!” (Kuntowijoyo, 2017: 36)

Penghuni pasar bereaksi sangat brutal, mereka mengejar burungburung dan membunuhnya. Sebagian pedagang akhirnya menghadap Pak Mantri untuk minta ganti rugi karena dagangannya ditumpahkan burung dara sehingga tidak lagi memiliki modal untuk berjualan di esok hari.

Pak Mantri dalam menanggapi laporan Paijo justru menganggap bahwa para pedagang sudah memberontak. Menurut Pak Mantri, penolakan membayar pajak itu merupakan pemberontakan kepada negara. Karena pasar ini adalah milik negara. Alasan bahwa pedagang rugi karena burung dara itu merupakan alasan yang dibuat-buat. Logikanya, mana ada burung dapat dipersalahkan atas terganggunya ekonomi.

Masyarakat pasar dengan tegas memberikan alasan tidak mau membayar karcis. Penolakan pembayaran pajak oleh pedagang dapat dimaklumi. Wajar jika mereka marah dan menuntut ganti rugi. Karena mereka selalu membayar pajak namun tidak diberikan kenyamanan dan keamanan. Melihat dari sisi Pak Mantri Pasar, dia tidak menyadari bahwa semua yang terjadi adalah akibat burung dara miliknya. Jumlah burung dara miliknya sudah melampaui batas.

\section{Penolakan Pemerintah}

Protes pedagang pasar dan orang-orang yang sudah melukai dan membunuh burung dara tidak dihadapi sendiri oleh Pak Mantri, tetapi langsung dilaporkan kepada Pak Camat sebagai pihak pemerintah yang terdekat. Pak Mantri serius memberitahukan pengaduannya tentang pedagang yang protes. Pak Mantri melaporkan bahwa pedagang tidak mau membayar karcis, mereka melakukan pemogokan, dan pembangkangan. Pak Mantri ingin orang-orang itu dihukum. Pak Mantri menyerahkan daftar nama pedagang yang membangkang.

Pak Camat hanya sebatas menanggapi. Akan dilakukan pengusutan karena perkara ini serius jadi harus hati-hati, harus melalui prosedur. Pak Camat datang ke pasar memeriksa semuanya sesuai laporan Pak Mantri. Hasil pemeriksaan akan diatur lebih jauh, sedang dipelajari peraturan tentang itu. Pak Camat juga berkomentar tentang los-los tua di pasar yang tidak bisa menjamin keamanan para pedagang. Anjuran Pak Camat akan diberitahukan kemudian. Dengan penjelasan Pak Camat itu Pak Mantri merasa tidak puas dan tidak menyelesaikan masalah. 
Pak Mantri berpikir lagi untuk melaporkan masalah pasar ini ke polisi, karena tidak puas dengan apa yang dilakukan Pak Camat. Laporan bertambah lagi dengan adanya pasar yang didirikan oleh Kasan Ngali pedagang gaplek.

Laporan Pak Mantri tentang burung dara dianggap tidak penting oleh Kepala Polisi. Pembunuhan tentang burung bukan wewenang polisi katanya. Polisi hanya mengurus pembunuhan yang benar pembunuhan. Aturan mengenai pembunuhan burung dara belum diatur dalam undang-undang, atau bukan urusan polisi tetapi urusan pamong praja. Buktinya :

"Tetapi kami tak mengurusi pembunuhan burung-burung. Perkara semacam itu tugas pamong praja. Pak Camat tentu bisa, Pak. Polisi hanya mengurus pembunuhan yang benar-benar pembunuhan, begitu." (Kuntowijoyo, 2017: 87)

Laporan Pak Mantri ditampung dan akan dipertimbangkan untuk melakukan tindakan apa yang bisa dilakukan selanjutnya. Pak Mantri lega dengan jawaban kepala Polisi. Namun dirasanya bahwa laporan kepada polisi tidak banyak berhasil.

Aparat pemerintah merasa sungkan kepada Pak Mantri. Tidak ada keberanian untuk mengorek lebih dalam penyebab konflik tersebut karena menyangkut burung-burung dara Pak Mantri. Sebenarnya pejabat tahu penyebab kacaunya pasar disebabkan oleh burung dara.

Laporan yang disampaikan Pak Mantri, tanggapan wakil pemerintah hanya sekedar memeriksa dan meninjau lokasi. Tidak ada indikasi untuk memproses agar masalah pasar segera diselesaikan. Katidakseriusan ini mengakibatkan kurangnya kepercayaan rakyat kepada pejabat pemerintah. Dalam pekerjaannya, seorang Camat tidak memberikan contoh yang baik bagi masyarakat, terbukti ketika pada jam kerja Pak Camat menonton adu jago di belakang kantor kacamatan. Tiga hal sudah menyalahi aturan, yang pertama menonton adu jago, yang kedua pada jam kerja meninggalkan kantor untuk keperluan pribadi/kesenangan, yang ketiga melegalkan adu jago. Seharusnya seorang pejabat pemerintah menertibkan kebiasaan buruk masyarakat, adu jago tidak diperbolehkan karena melanggar peraturan yaitu selain judi juga menyakiti binatang. Tidak keluar kantor demi keisengan dan kesenangan dengan dalih selingan. Itu tidak dibenarkan.

Laporan Pak Mantri tidak berhasil menyelesaikan masalah. Semua dilakukan dengan tidak serius, menganggap hal itu masalah sepele tentang burung dara, mereka acuh-tak acuh, tidak andal menjalankan tugasnya, padahal menyangkut kenyamanan dan keamanan masyarakat pasar. Ironis, aparat tidak bisa menyelesaikan permasalahan pasar. Aparat tak tahu apa yang harus dikerjakan, yang ada dalam pikirannya hanya kesenangan.

\section{Pasar dan Bank Kredit Illegal Milik Kasan Ngali}

Pasar yang sedemikian semrawut dimanfaatkan oleh Kasan Ngali dengan cara membuka pasar baru dan bank kredit yang berada di pekarangan rumahnya yang luas. Membuka pasar dan bank kredit dengan dalih membantu para pedagang akibat tidak nyaman di pasar. 
“Benarlah! Ketika Paijo keluar dari rumah Kasan Ngali, ia terkejut. Di pekarangan Kasan Ngali sudah berdiri los-los pasar! Dan pedagangnya sekali. Tentu saja Kasan Ngali sengaja menggiring mereka ke pekarangannya." (Kuntowijoyo, 2017: 79)

Kasan Ngali adalah seorang pedagang gaplek yang cukup berhasil sehingga dia menjadi orang kaya di wilayah Gemolong. Keadaan tersebut menjadikan Pak Mantri merasa sangat terpukul. Orang-orang mulai menjauhinya dan membencinya.

Kasan Ngali, pedagang kaya yang hanya memikirkan keuntungan untuk dirinya sendiri. Kasan Ngali suka menimbun barang untuk dijual dengan harga tinggi pada musim paceklik. Juga mengenai pendirian bank kredit yang tidak mengajar orang untuk menabung, tetapi malah mengajar orang untuk berutang. Memberikan kredit hanya merangsang orang untuk hidup mewah, tidak untuk berproduksi. Pinjaman pun diberikan dengan meminta bunga pengembalian. Orang kaya yang tampaknya mau menolong, tetapi sebenarnya justru menyengsarakan orang miskin.

Kasan Ngali sangat lekat dengan kesombongan. Kasan Ngali selalu berusaha memamerkan kekayaannya. Ia selalu beranggapan bahwa dengan uang ia dapat melakukan segala yang diinginkannya; merendahkan orang lain, membeli mobil, mendapatkan perempuan, memiliki orang-orang pasar, memiliki burung dara, dan sebagainya. Ketika memiliki mobil baru, ia pun memarkirnya di dekat pasar supaya dilihat banyak orang. Jika memberikan sesuatu pada orang lain tidak didasari sikap kerelaan. Namun, Kasan Ngali hanya ingin memamerkan kekayaan. Bahkan seringkali juga untuk mengharapkan hasil (keuntungan) yang lebih besar. Ia memberikan hadiah kepada Zaitun dengan maksud untuk mendapatkan cinta Zaitun. Ia membantu dengan memberikan kredit pada orang-orang pasar, tetapi juga mengharuskan mereka untuk membayar bunga pinjaman itu. Membeli gaplek pada orangorang untuk dijual dengan harga yang tinggi pada musim paceklik.

Kasan Ngali mengatur berbagai strategi dalam rangka memamerkan kekayaannya kepada Siti Zaitun. Jadi, motivasi seluruh tindakan Kasan Ngali adalah Siti Zaitun. Untuk melaksanakan strateginya itu, Kasan Ngali memanfaatkan situasi. Semua tindakan Kasan Ngali hanya untuk menarik perhatian Siti Zaitun.

Pasar dan bank kredit illegal ini menjadi masalah besar bagi Kepala Pasar. Dia tidak bisa menghentikan apa yang dilakukan Kasan Ngali. Pak Mantri tahu bahwa Kasan Ngali menyalahi aturan hukum, tetapi dia tidak mampu untuk menegur. Bagaimana bisa menegur, karena adanya pasar illegal dan bank pasar ini juga disebabkan oleh masalah yang terjadi di pasarnya.

\section{Kesadaran Pak Mantri yang Menyelamatkan Pasar}

Pengarang dalam menyelesaikan konflik novel ini sangat manis. Dalam menghadapi permasalah yang semakin lama semakin memuncak, terjadinya kurang kepercayaan para pedagang kepada Pak Mantri dan tidak adanya putusan penyelesaian masalah pasar oleh pejabat pemerintah setempat, maka pak Mantri merenung dalam dirinya. Dalam perenungannya dia mulai sadar 
dengan apa yang terjadi, sadar akan apa yang menjadi penyebab kisruhnya pasar. Sadar akan nilai-nilai moral yang sangat berarti untuk menyelesaikan masalah dan melanjutkan kehidupan. Menyadari kekeliruannya bahwa burungburung dara itulah penyebab semuanya. Sadar bahwa dia menjalankan tugas telah menggunakan kekuasaannya sebagai Kepala Pasar. Dalam kesadarannya banyak nilai-nilai Jawa yang muncul dalam benaknya yang selama ini dia pegang teguh sebagai prinsip hidupnya.

"Sambil tiduran ia memikirkan, kalau perlu burung-burung daranya bisa saja ditangkap. Supaya orang-orang pasar selamat. Tentang caranya bisa diserahkan pada Paijo. Keputusannya yang luar biasa itu memberi harapan, bahkan baginya sendiri.dan ia setuan itu mempunyai kerelaan yang demikian besar. Semoga diterima amalnya!” (Kuntowijoyo, 2017: 260)

Pak Mantri dalam pergulatan menghadapi perubahan di masyarakatnya, sebagai orang Jawa, seharusnya menjauhkan diri dan membenci watak adigang, adigung, adiguna. Watak adigang adalah watak sombong, karena mengandalkan kekayaan dan pangkat. Watak adigung adalah watak sombong karena mengandalkan kepandaian dan kepintaran, lantas meremehkan orang lain. Padahal, Pak Mantri termasuk orang yang punya jabatan dan disegani oleh orang di kecamatan itu. Rasanya menjadi malu jika melihat kelakuan sendiri seperti itu.

Pak Mantri dalam menghadapi ulah Kasan Ngali yang mendirikan pasar baru dan Bank Kredit, akhirnya tidak terburu nafsu untuk marah atau melabrak Kasan Ngali. Bagi Pak Mantri kemarahan justru akan menjatuhkan namanya sendiri. Dengan sikap rereh, ririh, dan ngati-ati, berarti manusia dapat menguasai nafsunya. Manusia akan sempurna bila dapat menguasai nafsu. Sementara itu, orang yang dikuasai nafsu akan berbahaya bagi orang-orang di sekitarnya. Dengan sikap rereh, ririh, dan ngati-ati tentu akan dapat melahirkan penyelesaian yang baik.

Orang Jawa memiliki pandangan hidup yang selalu mengutamakan rasa juga digunakan Pak Mantri untuk menyelesaikan segala persoalan yang dihadapinya, sehingga ia berhasil menyelesaikan persoalan yang dihadapinya dengan baik. Ia mampu mengambil suatu keputusan yang bagi orang lain sangat luar biasa, yaitu ia memberikan burung-burung dara yang selama ini sangat dicintainya kepada siapa saja yang ingin memilikinya. Ia menganggap hal itu sebagai sedekah. Keputusan ini tidak menunjukkan kekalahan Pak Mantri, tetapi justru suatu kemenangan. Karena keputusan tersebut didasari oleh kesadaran Pak Mantri bahwa burung-burung daranya selama ini telah sering merepotkan para pedagang. Pak Mantri mengakui kesalahannya. Di samping itu, keputusan tersebut juga didasari sifat rela berkorban demi kepentingan orang banyak. Di samping itu, Pak Mantri juga memutuskan untuk pensiun agar yang muda bisa menggantikan.

\section{Kasan Ngali Bangkrut}

Kasan Ngali selalu tergesa-gesa dalam bertindak. Untuk menuruti nafsunya, Kasan Ngali tidak berpikir matang. Bahkan jika perlu menghalalkan 
segala cara. Asalkan hal yang dikehendakinya segera tercapai. Untuk menguasai orang pasar, ia mendirikan pasar baru, mendirikan bank kredit. Untuk mendapatkan Zaitun, ia membeli mobil, dan sebagainya.

Pasar swasta dan bank kredit milik Kasan Ngali itu mengundang pertikaian dan bahaya karena dapat mengancam keberadaan pasar resmi (Pak Mantri) dalam pelayanan publik dan pendapatan negara berupa pajak pasar yang berasal dari penarikan karcis pasar serta mengancam keberlangsungan hidup bank resmi (Siti Zaitun).

Kasan Ngali akhirnya kekayaannya ludes, gara-gara pamer kekayaan untuk mendapatkan Siti Zaitun dan Sri Hesti. Kini dia sadar, bahwa tindakannya menghambur-hamburkan uang adalah suatu kebodohan. Hingga akhirnya dia justru menderita kerugian, jatuh bangkrut, sementara apa yang diharapkannya tidak terwujud.

"Sekarang sudah bubar! Uang siapa kalian kira! Uang buyutmu! Uang kakekmu! Tidak ada lagi kredit! Tidak ada uang! Pemerasan!” (Kuntowijoyo, 2017: 344)

Kasan Ngali memupus keinginannya untuk menikah yang keenam kali dengan Siti Zaitun. Demikian pula, keinginannya untuk menikahi Sri Hesti diurungkannya. Kasan Ngali hanya bisa melihat dari jauh Siti Zaitun pulang ke kampungnya. Kasan Ngali sadar akan kekeliruannya.

\section{SIMPULAN}

Berdasarkan hasil penelitian tentang Kaitan Konflik dan Nilai-Nilai Sosial dalam Novel Pasar Karya Kuntowijoyo penulis dapat mengambil kesimpulan sebagai berikut:

1. Mengungkapkan deskripsi pertentangan pengguna pasar dan pengelola pasar yang menimbulkan konflik sosial. Konflik sosial disebabkan oleh burungburung dara milik Pak Mantri dan kepentingan-kepentingan pribadi para tokoh. Syukurlah pejabat menyadari kesalahannya di akhir novel.

2. Konflik benar terjadi. Konflik ini membawa perubahan sosial dalam setiap aspek kehidupan yang berkaitan dengan nilai-nilai sosial dalam masyarakat. Nilai sosial tersebut adalah tidak adanya tanggung jawab, penggunaan kekuasaan, dan ketidakpedulian terhadap situasi..

\section{DAFTAR PUSTAKA}

Al-Ma'ruf, A. I. (2006). Dimensi sosial keagamaan dalam fiksi Indonesia modern fenomena perkawinan lintas agama dalam novel Keluarga Permana karya Ramadhan KH: Kajian semiotik. https://publikasiilmiah.ums.ac.id/xmlui/ bitstream/handle/11617/2094/CHAPTER\%20I.pdf?sequence=2

Damono, S. D. (1979). Sosiologi sastra sebuah pengantar ringkas. Jakarta: Pusat Pembinaan dan Pengembangan Bahasa Departemen Pendidikan dan 
Kebudayaan.

Kuntowijoyo. (2017). Pasar. Yogyakarta: DIVA Press.

Rahman, F., Anto, P., \& Maskur, A. (2018). Interferensi bahasa arab terhadap bahasa Indonesia dalam percakapan santri (Kajian pada Novel Negeri 5 Menara). Imajeri: Jurnal Pendidikan Bahasa dan Sastra Indonesia, 1(1), 12-23.

Semi, A. (1998). Anatomi sastra. Padang: Angkasa Raya.

Wellek, R., \& Warren, A. (1989). Teori kesusastraanI. (Terj. Melani Budianta). Jakarta: PT Gramedia 